\title{
THE STATE OF PLATELET HEMOSTASIS IN PATIENTS WITH HYPERTENSIVE DISEASE COMBINED WITH NON-ALCOHOLIC FAT LIVER DISEASE
}

\author{
Bazhenova N.M. https://orcid.org/0000-0002-5640-4317 \\ Bogomolets National Medical University, Kyiv, Ukraine
}

dr.bazhenova@gmail.com

\begin{abstract}
Relevance. Platelet activation and platelet aggregation are central processes in the pathophysiology of coronary heart disease and thrombosis. The relationship between cardiovascular morbidity and mortality varies with the presence of other concomitant cardiovascular risk factors.

Objective. To determine the state of platelet hemostasis in patients with essential hypertension (HT), with concomitant non-alcoholic fatty liver disease (NAFLD).

Materials and methods. 152 patients were examined: 72 men and 80 women. Three groups were identified: I - 46 patients with stage II HT without concomitant NAFLD, II - 54 patients with NAFLD without HT, group III - 52 patients with HT and concomitant NAFLD. A study of total platelet count, mean platelet volume (MPV), platelet distribution width (PDW), platelet count (PCT) and spontaneous platelet aggregation was performed.

Results. The level of mean platelet volume (MPV) in both groups of patients with hepatic steatosis exceeded control values equally - by $6 \%$, both in patients with NAFLD $(\mathrm{p}<0.001)$ and in NAFLD with concomitant hypertension $(\mathrm{p}<0.01)$. In patients of the NAFLD group and hypertension, the relative width of the platelet distribution by volume (PDW) had high values $-2 \%(\mathrm{p}<0.05)$ higher than in the control cohort, and $2.4 \%(\mathrm{p}<0.05)$ than in patients with isolated HT. An increase in the degree of spontaneous aggregation in patients of all surveyed groups compared to controls. So in patients with HT II stage. spontaneous aggregation increased 2.2 times ( $<<0.001)$, while in both groups of patients with hepatic steatosis, the increase in spontaneous platelet activity was twice as high: in patients with NAFLD - 4.3 times $(\mathrm{p}<0.001)$, in patients with HT II stage. and concomitant NAFLD - 4.1 times $(\mathrm{p}<0.001)$.

Conclusion. NAFLD is accompanied by an increased in MPV, the size of which correlates with their functional activity. In patients with isolated NAFLD, a statistically significant increase in spontaneous platelet aggregation is also observed, which allows considering NAFLD as one of the risk factors for thrombophilic changes in the primary hemostasis.
\end{abstract}

Keywords: non-alcoholic fatty liver disease; mean platelet volume; platelet aggregation; hypertonic disease; obesity.

Relevance. In modern society, non-alcoholic fatty liver disease (NAFLD) is the leading cause of liver disease. The global prevalence of NAFLD in the world is $25.2 \%$ [1]. Today NAFLD is recognized as a hepatic manifestation of metabolic syndrome [2]. Metabolic comorbidities associated with NAFLD include obesity 51.3\%, type 2 diabetes mellitus $22.5 \%$, hyperlipidemia $69.2 \%$, metabolic syndrome $42.5 \%$ and hypertension $39.3 \%$. In 2018 , Oikonomou D. et. al. analyzed the relationship of NAFLD with hypertension (HT) independently of other components of the metabolic syndrome, such as obesity and diabetes. It was found that NAFLD is associated with newly detected HT, while elevated blood pressure is associated with the development of fatty liver disease and subsequent progression of fibrosis [3]. Insulin resistance and activation of the renin-angiotensin-aldosterone system may provide potential pathophysiological links between these diseases. Inhibitors of the renin-angiotensin-aldosterone system have been studied in NAFLD, their use has created a favorable profile, reducing insulin resistance and the progression of fibrosis [3]. The results of this study confirm the existence of cardiometabolic links between NAFLD and HT.

Therefore, NAFLD should be considered not only as a liver disease, but also as an early mediator of cardiovascular disease, type 2 diabetes, obesity and dyslipidemia.
NAFLD is widespread in the general population and is associated with an increase in cardiovascular morbidity and mortality [2]. The main mechanisms and pathogenesis of the growth of cardiovascular morbidity and mortality in NAFLD are not yet fully understood. Therefore, we draw our attention to the study of the presence of thrombogenic conditions in the blood in combination with NAFLD with one of the most common diseases of the cardiovascular system - HT.

The primary link responsible for thrombus formation is platelet hemostasis. The role of platelets in the atherosclerotic process, and later in the pathophysiological mechanisms of cardiovascular disease, is not limited to the normal physiological role of platelets in the maintenance and implementation of hemostasis, they also simulate inflammatory responses and immune response. This interaction contributes to the localized inflammatory response and the progression of the atherosclerotic process [4].

Due to the fact that the production of peripheral platelets is regulated mainly by thrombopoietin, which is mainly synthesized in the liver, so the level of platelets in liver disease falls under meticulous study. According to the results of recent studies, people with NAFLD have an increased risk of decreased platelet count compared 
to those who do not have NAFLD $[5,6]$. However, the question of the nature of hemostatic complications in these patients remains open. Therefore, we analyzed the effect of NAFLD on the state of platelet hemostasis in patients with isolated NAFLD and the combined course of NAFLD with HT II.

The objective is determination of the state of platelet hemostasis in patients with hypertension combined with non-alcoholic fatty liver disease.

\section{MATERIALS AND METHODS}

The study was conducted on the clinical basis of the Department of Propaedeutics of Internal Medicine №1 National Medical University named after OO Bogomolets of the Kyiv Clinical Hospital on railway transport №2 Branch "Health Center" of "Ukrainian Railways" in the period 2015-2018. 152 patients were examined: 72 men and 80 women. Patients were divided into groups: Group I - patients with stage II HT without signs of liver damage (46 people, age of the examined 58.0 [51.0; 63.0] years); Group II - patients with NAFLD without HT (54 people, age 54.0 [43.0; 58.0] years); Group III patients with stage II HT with NAFLD (52 people, age 57.5 [48.0; 64.5] years). The control group consisted of 15 practically healthy individuals comparable in age and sex (age 49.0 [42.0; 55.0] years), who underwent a preventive examination.

The study was conducted in accordance with the Code of Ethics of the World Medical Association (Declaration of Helsinki) and approved by the Commission on Bioethics of the Bogomolets National Medical University, expert opinion №97 dated 23.06.2016. All patients included in the study gave written informed consent to participate in the study.

All patients underwent general clinical studies. The laboratory study included determination of total blood counts, including total platelet count, mean platelet volume (MPV), platelet distribution width (PDW) and platelet count (PCT), using an automatic hematology analyzer Mindray BC 2800 (Mindray, China), with counting technology based on the conductometric method, in which cells pass through an aperture of small size.

To achieve this goal, a study of spontaneous platelet aggregation was performed. Platelet aggregation activity was studied using a 230-LA aggregation laser analyzer (Biola Research and Production Company, Russia). The critical level of significance in testing statistical hypotheses was assumed to be 0.05 . Non-parametric statistical methods were used for statistical analysis: U-Mann-Whitney test, Kruskal-Wallis H-test, Spearman correlation coefficient, odds ratio (OR), as small sample sizes were used, and values in groups were not subject to the law of normal distribution.

\section{RESULTS AND DISCUSSION}

We studied the indicators that characterize platelets: PDW - the calculated width of the curve of platelet distribution by volume or the relative width of platelet distribution by volume; this is an indicator of platelet heterogeneity; PCT - plateletcrit, an indicator that characterizes the percentage of platelet mass in the blood volume; MPV - mean platelet volume, which is determined based on the histogram of platelet distribution.

MPV analysis showed a significant increase in this indicator only in groups with NAFLD, while in patients with isolated course of HT the difference was not significant. The level of MPV in both groups of patients with hepatic steatosis exceeded the control values to the same extent - by $6 \%$, both in patients with NAFLD $(p<0.001)$ and NAFLD combined with HT $(\mathrm{p}<0.01)$. Intergroup comparisons did not reveal significant differences between the examined groups of patients (Table 1).

Table 1

Platelet status in the examined groups of patients (Me $[25 \% ; 75 \%]$ )

\begin{tabular}{|l|l|l|l|l|}
\hline \multicolumn{1}{|c|}{ Group } & $\begin{array}{l}\text { Platelets, } \\
10^{9} / \mathrm{L}\end{array}$ & MPV, fL & PDW, \% & PCT, $\%$ \\
\hline $\begin{array}{l}\text { HT (I) } \\
(\mathrm{n}=46)\end{array}$ & 253 & 9.7 & 14.7 & 0.248 \\
& {$[214 ;$} & {$[9.2 ;$} & {$[14.5 ;$} & {$[0.227 ;$} \\
& $288]$ & $10.1]$ & $14.8]$ & $0.282]$ \\
\hline $\begin{array}{l}\text { NAFLD (II) } \\
(\mathrm{n}=54)\end{array}$ & 235 & $9.9 * * *$ & 14.8 & 0.241 \\
& {$[207.5 ;$} & {$[9.7 ;$} & {$[14.6 ;$} & $0.216 ;$ \\
\hline $\begin{array}{l}\text { NAFLD+HT } \\
(\text { III }) \\
(\mathrm{n}=52)\end{array}$ & $2240]$ & $10.3]$ & $14.9]$ & $0.276]$ \\
\hline Control & {$[211 ;$} & $9.9 * *$ & 14.9 & 0.236 \\
& $258.5]$ & $10.3 ;$ & {$[14.6 ;$} & $0.216 ;$ \\
& 242.5 & 9.4 & $15.1]$ & $0.260]$ \\
\hline $\mathrm{p}_{1-2}$ & $206 ;$ & {$[9.1 ; 9.7]$} & {$[14.4 ;$} & 0.247 \\
\hline $\mathrm{p}_{1-3}$ & $\mathrm{p}>0.05$ & $\mathrm{p}>0.05$ & $\mathrm{p}>0.05$ & $\mathrm{p}>0.05$ \\
\hline $\mathrm{p}_{2-3}$ & $\mathrm{p}>0.05$ & $\mathrm{p}>0.05$ & $\mathrm{p}<0.05$ & $\mathrm{p}>0.05$ \\
\hline & $\mathrm{p}>0.05$ & $\mathrm{p}>0.05$ & $\mathrm{p}>0.05$ & $\mathrm{p}>0.05$ \\
\hline
\end{tabular}

Notes: p1-2 - the probability of the difference between patients of group I and group II; p1-3 - the probability of the difference between patients of group I and group III; p2-3 the probability of the difference between patients of group II and group III. The degree of probability of indicators relative to the surveyed control group: ${ }^{*}-p<0.05 ; *^{*}-p<0.01$; $* * *$ - $p<0.001 ; M P V-$ mean platelet volume; $P D W-$ the relative width of the distribution of platelets by volume; $P C T$ - plateletcrit

Comparative analysis of the relative width of the distribution of platelets by volume (PDW) showed the highest values in the combined course of NAFLD and HT. In patients from this group PDW was $2 \%(\mathrm{p}<0.05)$ higher than in the control cohort, and $2.4 \%(\mathrm{p}<0.05)$ than in patients with isolated HT.

The level of plateletcrit (PCT), as well as the level of platelets in any of the examined groups did not differ 
significantly compared with the control cohort and in the intergroup analysis. Given that the study included patients with NAFLD only in the stage of hepatic steatosis, and did not include patients with steatohepatitis, fibrosis and cirrhosis of the liver, so the difference in PCT and platelet counts did not differ significantly.

It should be noted that we separately performed the distribution of patients by MPV values that exceeded the average of healthy individuals. This allowed us to detect a more pronounced and statistically significant increase in the frequency of high degrees of spontaneous and induced aggregation in patients with NAFLD and in combination with NAFLD with HT (Fig. 1).

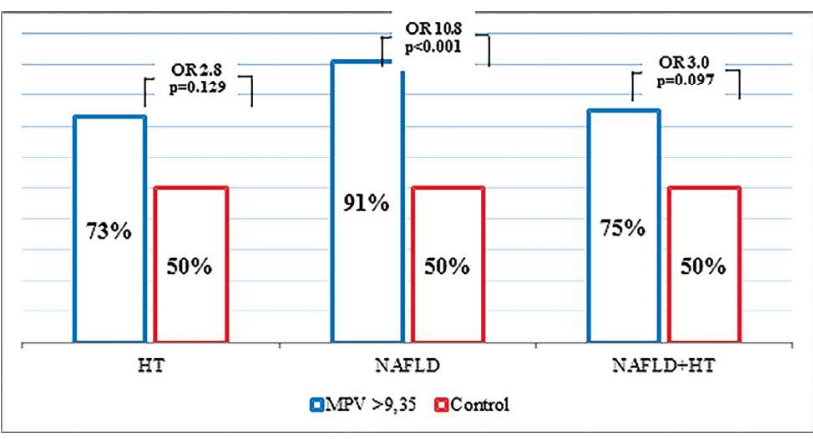

Fig. 1. The chance to find an increased mean platelet volume among the examined groups of patients

The results of the analysis proved that NAFLD was associated with a higher average platelet volume - MPV greater than $9.35 \mathrm{fL}$, the odds ratio was 10.75 (2.483$46.539)(p<0,001)$ under conditions of very high sensitivity $91.5 \%$ ), and the average values of specificity $(\mathrm{Sp}=50 \%)$ of this method in relation to the control. The combined course of NAFLD with HT of the II degree was also associated with the increased average volume of thrombocytes. - the odds ratio reached $3.0(0.803-11.211)$ $(\mathrm{p}=0.097)$ with high specificity $(\mathrm{Sp}=75 \%)$ and average values of the sensitivity of the method $(\mathrm{Se}=50 \%)$ to the control. In patients with HT, the frequency of large values of MPV, although higher than the control cohort, but did not reach a statistically significant difference $(\mathrm{OR}=2.75$ $(0.732-10.333), p=0.129)$ relative to control. Thus, the additional distribution of the incidence of high MPV values among the examined groups of patients confirmed the relationship between NAFLD and the increase in mean platelet volume.

Therefore, after analyzing the obtained data, we noted that the level of MPV was significantly higher among patients with NAFLD, regardless of the presence or absence of concomitant stage II HT.

The next step was to study the functional activity of platelets - spontaneous aggregation.

Platelet aggregation is the primary link in the complex mechanism of thrombus formation. The study of spontaneous aggregation reflects the thrombophilic activity of the blood at the initial stage of coagulation, the tendency to spontaneous thrombosis, and, accordingly, the risk of thrombogenic complications. We determined the spontaneous platelet aggregation in groups of patients with HT, NAFLD and combined pathology. After analyzing the data obtained, a significant increase in the degree of spontaneous aggregation in patients of all examined groups compared with the control. So in patients with HT spontaneous aggregation increased 2.2 times $(p<0.001)$, while in both groups of patients with hepatic steatosis, the increase in spontaneous platelet activity was twice as high: in patients with NAFLD - 4.3 times $(\mathrm{p}<0.001)$, in patients with HT and concomitant NAFLD - 4.1 times $(\mathrm{p}<0.001)$ (Fig. 2.).

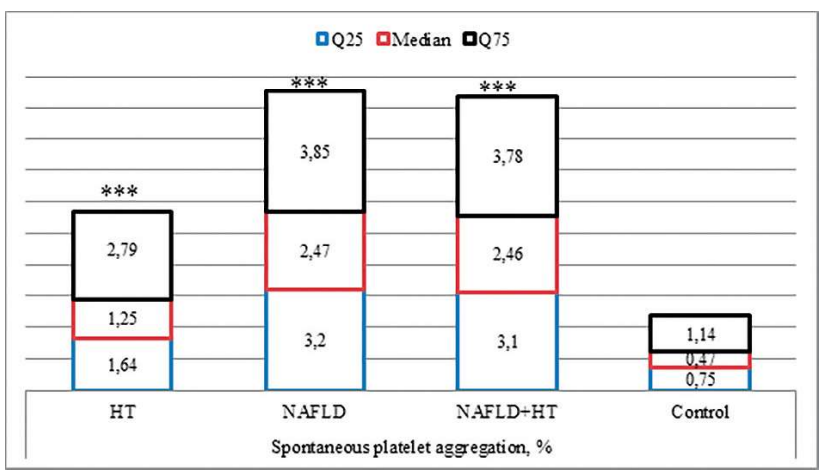

Fig. 2. Spontaneous platelet aggregation in different groups of patients in comparison with the control group by the Mana-Whitney method

Note: The degree of probability to the control group: *** $-p<0,001$

An intergroup comparison of spontaneous platelet aggregation was also performed. The comparison with a group of patients with HT showed that the degree of spontaneous aggregation was higher among patients in both groups with NAFLD: both in combination with HT, and in isolated NAFLD - 1.9 times $(\mathrm{p}<0.001)$ compared with the group of patients with HT. Probable difference between the values of spontaneous aggregation between NAFLD and NAFLD groups with HT not installed. The rate of spontaneous aggregation changed only in the group of combined course of NAFLD with HT and was 2.3 times $(\mathrm{p}<0.001)$ higher than in healthy patients, and to the same extent -1.7 times $(p<0.001)$ higher than in patients with isolated course of HT, and independent NAFLD. The time of spontaneous platelet aggregation increased in all groups of patients equally - three times $(\mathrm{p}<0.001)$, compared with control values.

After analyzing the relationships between the values of mean platelet volume and the level of spontaneous aggregation, we showed the existence of a weak positive correlation between the level of MPV and the degree of spontaneous aggregation $(\mathrm{r}=0.246$; $\mathrm{p}<0.05$ ) (Fig. 3). Such a connection is probably due to the content of a larger number of granules in the platelets of a larger volume. with endothelial cells and leukocytes [8]. 


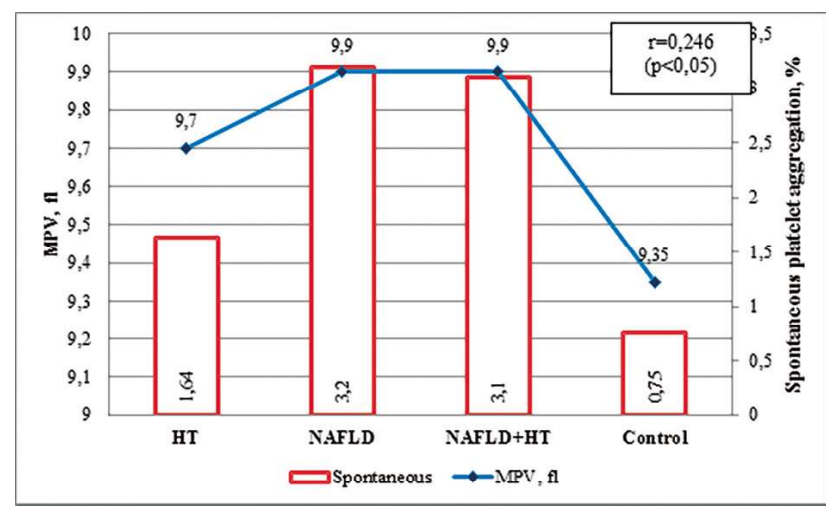

Fig. 3. Correlation spontaneous platelet aggregation by value of mean platelet volume in four groups

Note: $r$ - the Spearman correlation.

Having studied the data of spontaneous platelet aggregation, we found that in patients with HT there is an increase in the functional activity of platelets, which corresponds to the literature data [9], the severity of aggregation increases significantly with the addition of NAFLD. In patients with isolated NAFLD, a statistically significant increase in spontaneous platelet aggregation is also observed, which allows us to consider NAFLD as one of the risk factors for thrombophilic changes in the primary link of hemostasis. Also, we noted that the level of MPV was significantly higher among patients with NAFLD, regardless of the presence or absence of concomitant stage II HT. Given that in the general population, elevated levels of MPV (but not platelets) are associated with ischemic diseases, including acute myocardial infarction, as well as with an increased incidence of restenosis after myocardial infarction. The risk of stroke increases with increasing MPV, and the likelihood of greater brain damage increases. Increased MPV also has a strong and independent association with venous thromboembolic disease, even in the absence of trauma, surgery, immobilization $[7,10]$. Therefore, the growth of this indicator among patients with NAFLD should be considered as an additional risk factor for thrombogenic complications.

Thus, summarizing the data obtained, we can state that we found an increase in the degree of spontaneous platelet aggregation in patients with HT indicates a higher risk of thrombotic events compared to healthy individuals. At the same time, the presence of both independent nosological form and combination with HT in patients with NAFLD increases the activity of platelets almost twice compared to the isolated course of HT, which indicates a more significant shift of blood towards thrombophilic changes.

\section{CONCLUSIONS}

In patients with HT there is an increase in platelet aggregation activity by 2.2 times ( $<<0.001)$, the severity of which progresses significantly with the addition of NAFLD - an increase of 4.1 times $(p<0.001)$. In patients with isolated nonalcoholic fatty liver disease there is an increase in spontaneous platelet aggregation by 4.1 times $(p<0.001)$, which allows us to consider NAFLD as one of the risk factors for thrombophilic changes in the primary link of hemostasis. NAFLD is accompanied by an increase in mean platelet volume (MPV) of $6 \%$ $(\mathrm{p}<0.001)$, the size of which correlates with their functional activity $(r=0.246(p<0.05))$. Therefore, the increase in MPV in patients with NAFLD and in combination with NAFLD with HT is an additional factor in increasing the prothrombogenic activity of the blood.

Conflict of interest. The author declares no conflict of interest.

Funding. This research did not receive any specific grant from funding agencies in the public, commercial, or not-forprofit sectors

\section{REFERENCES}

1. Younossi Z.M., Koenig A.B., Abdelati D., Fazel Y., Henry L, Wymer M. Global epidemiology of nonalcoholic fatty liver disease-meta-analytic assessment of prevalence, incidence, and outcomes. Hepatology. 2016;64(1):73-84. DOI: 10.1002/hep.28431

View at: Publisher site: https://aasldpubs.onlinelibrary. wiley.com/doi/full/10.1002/hep.28431

PubMed: https://pubmed.ncbi.nlm.nih.gov/26707365/

2. Fotbolcu H., Zorlu E. Nonalcoholic fatty liver disease as a multi-systemic disease. World journal of gastroenterology. 2016;22(16):4079-90. DOI: 10.3748/wjg. v22.i16.4079

View at: Publisher site: https://www.wjgnet.com/10079327/full/v22/i16/4079.htm

PubMed: https://pubmed.ncbi.nlm.nih.gov/27122660/ PubMed Central: https://www.ncbi.nlm.nih.gov/pmc/ articles/PMC4837427/

3. Oikonomou D., Georgiopoulos G., Katsi V., Kourek C., Tsioufis C., Alexopoulou A., Koutli E., Tousoulis D. Non-alcoholic fatty liver disease and hypertension. European Journal of Gastroenterology \& Hepatology. 2018;30(9):979-85. DOI: 10.1097/ MEG.0000000000001191

View at: Publisher site: https://journals. 1ww.com/eurojgh/Abstract/2018/09000/ Non_alcoholic_fatty_liver_disease_and.1.aspx PubMed: https://pubmed.ncbi.nlm.nih.gov/30048367/

4. Papapanagiotou A., Daskalakis G., Siasos G., Gargalionis A., Papavassiliou A.G. The role of platelets in cardiovascular disease: molecular mechanisms. Current pharmaceutical design. 2016;22(29):4493-505. DOI: 10 .2174/1381612822666160607064118

View at: Publisher site: https://www.eurekaselect. com/143022/article

PubMed: https://pubmed.ncbi.nlm.nih.gov/27281334/

5. Panke C.L., Tovo C.V., Villela-Nogueira C.A. et al. Evaluation of thrombocytopenia in patients with non-al- 
coholic fatty liver disease without cirrhosis. Annals of Hepatology. 2020;19(1):88-91. DOI: 10.1016/j. aohep.2019.05.011.

View at: Scopus: https://www.sciencedirect.com/ science/article/pii/S1665268119322306?via\%3Dihub PubMed: https://pubmed.ncbi.nlm.nih.gov/31575467/

6. Liu F. Zhou H., Cao L. et al. Risk of reduced platelet counts in patients with nonalcoholic fatty liver disease (NAFLD): a prospective cohort study. Lipids in Health and Disease. 2018; 17(1):221. DOI: 10.1186/ s12944-018-0865-7

View at: Publisher site: https://lipidworld.biomedcentral.com/articles/10.1186/s 12944-018-0865-7

PubMed: https://pubmed.ncbi.nlm.nih.gov/30227874/

PubMed Central: https://www.ncbi.nlm.nih.gov/pmc/ articles/PMC6145189/

7. Abeles R.D., Mullish B.H., Forlano R. et al. Derivation and validation of a cardiovascular risk score for prediction of major acute cardiovascular events in non-alcoholic fatty liver disease; the importance of an elevated mean platelet volume. Alimentary Pharmacology \& Therapeutics. 2019;49(8):1077-85. DOI: 10.1111/apt. 15192

View at: Publisher site: https://onlinelibrary.wiley.com/ doi/full/10.1111/apt.15192

PubMed: https://pubmed.ncbi.nlm.nih.gov/30836450/ PubMed Central: https://www.ncbi.nlm.nih.gov/pmc/ articles/PMC6519040/

8. Ranucci M., Aloisio T., Di Dedda U., La Rovere M.T., De Arroyabe B.M.L., Baryshnikova E. Platelet reactivity in overweight and obese patients undergoing cardiac surgery. Platelets. 2019;30(5):608-14. DOI: 10.1080/09537104.2018.1492108

View at: Publisher site: https:/www.tandfonline.com/ doi/abs/10.1080/09537104.2018.1492108?journalCode $=$ iplt 20

PubMed: https://pubmed.ncbi.nlm.nih.gov/29985729/

9. Medvedev I.N., Skoryatina I.A. [Aggregation properties of blood cells and vascular control over them in patients with arterial hypertension and dyslipidemia]. Russian journal of Cardiology. 2015;4(120): 18-22. [in Russian] DOI: 10.15829/1560-4071-2015-4-18-22

View at: Publisher site: https://russjcardiol.elpub.ru/ jour/article/view/277/0

URL: https://russjcardiol.elpub.ru/jour/article/ viewFile/277/271

Cyberleninka: https://cyberleninka.ru/article/n/agregatsionno-dezagregatsionnye-yavleniya-v-krovi-pri-arterialnoy-gipertonii-s-dislipidemiey

10. 10. Zaccardi F., Rocca B., Pitocco D., Tanese L., Rizzi A., Ghirlanda G. Platelet mean volume, distribution width, and count in type 2 diabetes, impaired fasting glucose, and metabolic syndrome: a meta-analysis. Diabetes/Metabolism Research and Reviews. 2015;31(4):402-10. DOI: 10.1002/dmrr.2625

View at: Publisher site: https://onlinelibrary.wiley.com/ doi/abs/10.1002/dmrr.2625

PubMed: https://pubmed.ncbi.nlm.nih.gov/25421610/

\title{
СТАН ТРОМБОЦИТАРНОГО ГЕМОСТАЗУ У ХВОРИХ НА ГІПЕРТОНІЧНУ ХВОРОБУ У ПОСДНАННІ 3 НЕАЛКОГОЛЬНОЮ ЖИРОВОЮ ХВОРОБОЮ ПЕЧІНКИ
}

\author{
Баженова Н.М. \\ Начіональний медичний університет імені О.О. Богомольия, Київ, Украӥна \\ dr.bazhenova@gmail.com
}

\footnotetext{
Актуальність. Активація тромбоцитів і їх агрегації є центральними процесами в патофізіології ішемічної хвороби серця. Взаємозв'язок серцево-судинної захворюваності та смертності змінюється в залежності від наявності інших супутніх серцево-судинних факторів ризику.

Мета: визначити стан тромбоцитарного гемостазу у пацієнтів з гіпертонічною хворобою (ГХ), поєднаною 3 неалкогольною жировою хворобою печінки (НАЖХП).

Матеріали та методи. Обстежено 152 пацієнта: 72 чоловіка і 80 жінок. Виділено три групи: I - 46 хворих ГX II стадії, II 54 пацієнти з НАЖХП без ГХ, ІІІ група - 52 пацієнта з ГХ ІІ стадії з супутньою НАЖХП. Проводилось дослідження загальної кількості тромбоцитів, середнього об'єму тромбоцитів (MPV), ширини розподілу тромбоцитів (PDW) та тромбокриту (PCT) i спонтанної агрегаційної здатності тромбоцитів.

Результати. Рівень MPV в обох групах пацієнтів зі стеатозом печінки перевищував контрольні значення однаковою мірою - на $6 \%$, як у хворих на НАЖХП (p<0,001), так і на НАЖХП, поєднану з ГХ ІІ ст. (p $<0,01)$. У пацієнтів групи НАЖХП та ГХ II ст. PDW мала найвищі значення - на $2 \%(\mathrm{p}<0,05)$ вище, ніж в контрольній когорті, та на $2,4 \%(\mathrm{p}<0,05)$, ніж у пацієнтів 3 ізольованою ГХ ІІ ст. Спостерігали збільшення ступеня спонтанної агрегації у паціснтів всіх обстежених груп у порівнянні 3 контролем. Так, у пацієнтів з ГХ ІІ ст. спонтанна агрегація зростала в 2,2 рази (р<0,001), в той час в обох групах хворих, які страждали на стеатоз печінки, підвищення спонтанної активності тромбоцитів було вдвічі вищим: у пацієнтів з НАЖХП - в 4,3 рази ( $<0,001)$, у пацієнтів з ГХ ІІ ст. і супутньою НАЖХП - в 4,1 разів $(\mathrm{p}<0,001)$.
} 
Висновки. НАЖХП супроводжується зростанням середнього об'єму тромбоцитів, розмір яких корелює з їх функціональною активністю. У пацієнтів з ізольованою НАЖХП також спостерігається статистично значуще посилення спонтанної агрегації тромбоцитів, що дозволяс розглядати НАЖХП як один з факторів ризику тромбофілічних змін первинної ланки гемостазу.

Ключові слова: неалкогольна жирова хвороба печінки, середній об'єм тромбоцитів, агрегація тромбоцитів, гіпертонічна хвороба, ожиріння.

\title{
СОСТОЯНИЕ ТРОМБОЦИТАРНОГО ГЕМОСТАЗА У БОЛЬНЫХ ГИПЕРТОНИЧЕСКОЙ БОЛЕЗНЬЮ В СОЧЕТАНИИ С НЕАЛКОГОЛЬНОЙ ЖИРОВОЙ БОЛЕЗНЬЮ ПЕЧЕНИ
}

\author{
Баженова Н. М. \\ Начиональный медииинский университет имени А.А. Богомольиа, Киев, Украина \\ dr.bazhenova@gmail.com
}

Актуальность. Активация тромбоцитов и их агрегации являются центральными процессами в патофизиологии ишемической болезни сердца. Взаимосвязь сердечно-сосудистой заболеваемости и смертности меняется в зависимости от наличия других сопутствующих сердечно-сосудистых факторов риска.

Цель: определить состояние тромбоцитарного гемостаза у пациентов с гипертонической болезнью (ГБ), с сопутствующей неалкогольной жировой болезнью печени (НАЖБП).

Материалы и методы. Обследовано 152 пациента: 72 мужчины и 80 женщин. Выделены три группы: I - 46 больных ГБ II стадии, II - 54 пациента с НАЖБП без ГБ, III группа - 52 пациента с ГБ ІІ стадии с сопутствующей НАЖБП. Проводилось исследование общего количества тромбоцитов, среднего объема тромбоцитов (MPV), ширины распределения тромбоцитов (PDW), тромбокрита (РСТ) и спонтанной агрегационной способности тромбоцитов.

Результаты. Уровень MPV в обеих группах пациентов со стеатозом печени превышал контрольные значения в равной степени - на 6 \%, как у больных НАЖБП ( $<<0,001)$, так и при НАЖБП с сопутствующей ГБ ІІ ст. (р $<0,01)$. У пациентов группы НАЖБП и ГБ II ст. PDW имела высокие значения - на $2 \%(\mathrm{p}<0,05)$ выше, чем в контрольной когорте, и на $2,4 \%$ (p $<0,05)$, чем у пациентов с изолированной ГБ ІІ ст. Наблюдали увеличение степени спонтанной агрегации у пациентов всех обследованных групп по сравнению с контролем. Так, у пациентов с ГБ ІІ ст. спонтанная агрегация возрастала в 2,2 раза (p $<0,001)$, в то время в обеих группах больных, страдающих стеатозом печени, повышение спонтанной активности тромбоцитов было вдвое выше: у пациентов с НАЖБП - в 4,3 раза (p<0,001), у пациентов с ГБ ІІ ст. и сопутствующей НАЖБП - в 4,1 раза $(\mathrm{p}<0,001)$.

Выводы. НАЖБП сопровождается ростом среднего объема тромбоцитов, размер которых коррелирует с их функциональной активностью. У пациентов с изолированной НАЖБП также наблюдается статистически значимое усиление спонтанной агрегации тромбоцитов, что позволяет рассматривать НАЖБП как один из факторов риска тромбофилических изменений первичного звена гемостаза.

Ключевые слова: неалкогольная жировая болезнь печени, средний объем тромбоцитов, агрегация тромбоцитов, гипертоническая болезнь, ожирение. 